\title{
ФОРМУВАННЯ ГЕОГРАФІЧНИХ ПОНЯТЬ НА ОСНОВІ КОМПЕТЕНТНІСНОГО ПІДХОДУ ДО НАВЧАННЯ ГЕОГРАФІЇ УКРАЇНИ
}

Тросюк С. Д. Формування географічних понять на основі компетентнісного підходу до навчання географії України.

У статті розкрито поетапність процесу формування географічних понять на основі компетентнісного підходу до навчання географії України. Подано структурні конструкти у змісті формування географічних понять у процесі навчання географії України на рівні явищ, відношень і понять. Наведено зразки завдань для формування географічної компетенції на засадах компетентнісного підходу.

Ключові слова: географічні поняття, компетентнісний підхід, учні основної школи, природничі предмети.

Тросюк С. Д. Формирование географических понятий на основе компетентностного подхода к обучению географии Украины.

В статье раскрыта поэтапность процесса формирования географичсеких понятий на основе компетентностного похода к обучению географи Украины. Приведены структурные конструкты в содержании формирования географических понятий в процессе обучения географии Украины на уровне явлений, отношений и понятий. Приведены примеры заданий для формирования географической компетенции на основе компетентностного подхода.

Ключевые слова: географические понятия, компетентностный подход, ученики основной школы, природоведческие предметы.

Trosyuk S. D. Formation of geographical concepts competency-based approach to learning geography of Ukraine.

The article deals with the gradual process of the formation of concepts geografichsekih competency-based education campaign to geographic Ukraine. The structural constructs in forming the content of geographical concepts in the process of learning ce geographic Ukraine at the level of phenomena, concepts and relationships. Are examples of exercises in order to create jobs geographical competence competency-based approach.

Key words: geographical concepts, competence-based approach, students osnvonoy schools, natural history items.

Реформування освіти в Україні є чинником здійснення процесів оновлення освітніх систем. Ці процеси відбуваються останнім часом у європейських країнах і пов'язані 3 визнанням значущості знань як рушія суспільного добробуту і прогресу. Тож на часі створення нових освітніх стандартів, оновлення і перегляд навчальних програм, змісту навчально-дидактичних матеріалів, підручників, а також удосконалення форм і методів навчання географії в основній школі.

Нагальним стає перегляд в основній школі змісту і відповідних стандартів на засадах досягнення конкретного результату, вираженого в термінах ключових i предметних компетентностей, оптимальна інтеграція, диференціація, індивідуалізація й інформатизація, методичне забезпечення загальноосвітніх навчальних закладів на основі використання компетентнісно орієнтованих технологій навчання.

Формування географічної компетенції учнів основної школи у процесі навчання географії України корелює із якістю набутої географічної освіти на основі 
компетентнісного підходу, що актуалізує питання про змістове наповнення шкільного курсу географії поняттєво-категорійними елементами.

Питання вдосконалення методики навчання географії прямо чи опосередковано розглядали В. Герасимчук, Л. Зеленська, С. Кобернік, Р. Коваленко, В. Корнєєв, Л. Круглик, Т. Назаренко, О. Надтока, Я. Олійник, В. Онищук, М. Откаленко, В. Пестушко, Б. Пічугін, В. Сасихов, А. Сиротенко, О. Скуратович, М. Топузов, О. Топузов, О. Топчієв, Г. Уварова, Б. Чернов, С. Шипович, П. Шищенко, Б. Яценко.

Наявність значної кількості наукових праць не надає змоги всебічно розкрити проблему формування географічної компетенції учнів основної школи. У більшості досліджень недостатнього відображено проблему вибору змісту, форм, методів і технологій формування у свідомості учнів основних положень, які пов'язані 3 тематикою шкільних географічних курсів основної школи; не визначено і не узгоджено міждисциплінарні зв'язки і психолого-педагогічні закономірності процесу формування основних географічних компетенцій; неповною мірою розроблено систему формування географічних компетенцій, що грунтується на чіткому розумінні взаємозв'язку, взаємозалежності і взаємодії всіх важливих соціально-економічних процесів і явищ, що постійно відбуваються в житті суспільства, країни та глобальній системі природокористування; не зовсім досліджено систему визначення критеріїв та рівнів сформованості географічної компетенції в учнів.

Mema cmammi- розробити зміст процесу формування географічних понять на основі компетентнісного підходу до навчання географії України.

«Освіта, - за визначенням С. Гончаренка, - це процес і результат засвоєння особистістю певної системи наукових знань, практичних умінь і навичок і пов'язаного 3 ними того чи іншого рівня розвитку їі розумово-пізнавальної і творчої діяльності, а також морально-естетичної культури, які у своїй сукупності визначають соціальне обличчя та індивідуальну своєрідність цієї особистості» [2, с. 616]. Під освітою розуміють «процес взаємодії дорослих і дітей, що мають за мету створення культурних умов (як зовнішніх, так i внутрішніх) для саморозвитку i самовдосконалення особистості» [2, с. 100].

В основу поняття «освіта» покладено ідею саморегуляції людиною свого природного призначення, свого особистісного «Я», образ якого, як ідеал, повинний передбачати у свідомості людини його постійну освітню діяльність.

Основою педагогічної філософії «великої дидактики»є ідея творення людини 3 дитини. Цьому завданню і призначена освіта, «щоб людина стала людиною, вона повинна здобувати освіту» [3, с. 35]. Тому освіта людини має проходити на природному тлі волі розвитку ії вікових інтересів, природній допитливості, усвідомленого відкриття себе й навколишнього середовища. Освіту в науці і практиці розглядають як «рушійну силу людської життєдіяльності, що забезпечує постійний розвиток будь-якого суспільства» [3, с. 33].

Узагальнення викладеного вище дозволяє дійти висновку про те. що розроблення проблеми формування основних географічних понять в учнів основної школи нині корелює 3 аналізом історико-педагогічного досвіду України й культурнопросвітницьких традицій вітчизняної школи.

Наукові знання у галузі географії України як необхідний компонент географічної освіти містять певну сукупність наукових понять, логічно сформованих загальнонаукових думок про географічні явища, процеси, закони, категорії, які входять до предмета дослідження.

Формування i розвиток наукових понять, особливостей сутності проблеми $\epsilon$ водночас одним із найскладніших завдань у системі функціонування і розвитку будь- 
якої освіти, зокрема й географічної. Щодо окресленого питання педагог-психолог А. Виготський цілком слушно підкреслював: «Питання про розвиток наукових понять $€$ перш за все практичне питання великої, можливо, навіть найбільшої важливості з точки зору завдань, які стоять перед школою у зв'язку з навчанням дитини системі наукових знань» $[1$, с. 152].

Педагогічна наука в різні часи приділяла велике значення проблемі формування понять. При цьому, одним із визначальних питань, що привертали увагу філософів, психологів, педагогів, методистів, було питання про методику формування понять у процесі навчання.

Зокрема, як уважав Б. Ананьєв [6], однією із найважливіших закономірностей засвоювання будь-якої фундаментальної одиниці $\epsilon$ та, що будь-яке нове теоретичне поняття слід подавати не ізольовано, а в тісному зв'язку 3 іншими, вже відомим, включаючи його до загальної системи знань. Тобто формування у свідомості старшокласників сучасних країнознавчих понять неможливе без аналізу і систематизації знань учнів під час вивчення в школі суміжних предметів природничого циклу, а також під час процесу аналізу, осмислення та усвідомлення ними географічних явищ, явищ суспільно-політичного та суспільно-економічного життя країни.

Однією 3 відмінних особливостей формування будь-яких понять, а в цьому дослідженні - географічних, динамічність. Це має виняткове значення для розуміння того, що процес їх формування не обмежується засвоєнням якихось окремих, незмінних понять.

Процес формування основних понять тісно пов'язаний із питанням сутності предметів і явищ, які вони відображають. Зокрема, Н. Тализіна [2] і Н. Менчинська [2] стверджували, що для того, щоб сформувати в учнів певні поняття, необхідно передусім навчити їх визначати в предметі певні властивості; відрізняти суттєві й несуттєві ознаки, тобто важливі від другорядних; навчитись розпізнавати предмети, спираючись на суттєві ознаки.

Багато уваги дослідженню цього питання приділила відомий педагог-психолог €. Кабанова-Меллер [2]. Вона встановила, що засвоювання понять вимагає усвідомлення учнями не тільки постійних. суттєвих ознак об'єкта, а й усвідомлювання змінних, варіативних ознак; якщо усвідомлення останніх як таких затримується, то вводять їх у зміст понять, які добре засвоюються.

Аналіз науково-методичної літератури призводить до висновку, що формування географічних понять відбувається завдяки активній пізнавальній діяльності учнів, через організацію відповідних розумових операцій, спрямованих на географічні явища, закони, категорії, уявлення про які в них формуються.

Отже, формування географічних понять забезпечує розроблення змістового компонента географічної освіти, коли рівень сформованості географічних знань корелює із рівнем сформованості географічної компетенції учнів основної школи в процесі вивчення географії України.

Формування компетенцій, зокрема географічних, $є$ процесом динамічним, постійно домінуючим над соціумом, який покликаний формувати в учнів основної школи компетентнісний підхід до навчання. Сучасний практичний досвід проблеми географічної освіти в основній школі надав змогу зробити висновок, що серед важливих умов, які сприяють ефективному формуванню географічної компетенції, найпріоритетнішою $€$ наявність комплексної системи навчання шкільних курсів географії України задля вдосконалення змісту шкільної географічної освіти шляхом структурування ії змістового компонента. 
Концептуальна модель змістової структури географічних знань у структурі шкільного курсу географії становить системне поєднання двох рядів:

1) горизонтальний ряд, у межах якого знання представляють мікро-, макро- та глобальний рівні географічної теорії і господарської практики;

2) вертикальний ряд, у межах якого в ієрархічному підпорядкуванні перебувають рівні засвоєння географічних знань - факти, поняття i категорії, теорії (закони, закономірності, концепції), світоглядні ідеї і парадигми, що сприяє номологізації навчання.

Кінцевою метою формування географічних знань у загальній природничій освіті є усвідомлення учнями шляхів компромісного досягнення соціально-еколого-економічної ефективності під час виконання соціальних ролей у соціокультурній дійсності.

Аналіз шкільного курсу географії України, виучуваний в основній школі, дозволяє зробити припущення, що у процесі ї вивчення, 3 одного боку,- накопичується інформація, яку подає кожний предмет, з іншого, - відбувається інтеграція та набування знань, аналіз суті одиничних понять, тобто формування системи географічних знань, що зумовлює якісну трансформацію здобутих знань із певних компетенцій та формуванню остаточних уявлень, більш узагальнених та більш усвідомлених. При цьому не досягається спільна мета інтеграції зазначених курсів - формування в учнів системи теоретичних і практичних навичок щодо системи країнознавчої компетентності 3 подальшим поглибленням особистісної компетентності учнів щодо особливостей ії функціонування.

Задля аналізу, узагальнення і виявлення системності у формуванні країнознавчої компетентності в шкільних курсах географії проведено аналіз проблеми вивчення географічної освіти в основній школі. Це дало змогу дослідити формування в учнів різних теоретичних i практичних навичок, необхідних для досягнення успіху в подальшому самостійному житті, а саме - здатності мислити, аналізувати та робити відповідні висновки та дії.

Вивчення шкільного курсу географії передбачає певні психолого-педагогічні основи формування географічних знань в учнів основної школи, що передбачає такі процеси організації навчальної діяльності:

1. Засвоєння географічних понять - процес, який вимагає від учнів продуктивної пізнавальної діяльності, розвитку країнознавчого мислення.

2. Формування географічних понять здійснюється на основі уявлень на тому рівні пізнання, коли на зміну чуттєвому сприйняттю приходить абстрактне мислення, однак, в процесі навчання формування країнознавчих понять і уявлень відбувається одночасно.

3. Розкриття змісту географічних понять здійснюється на основі виокремлення суттєвих і несуттєвих ознак, що вивчаються, встановлюється певний зв'язок між ними: a) поняття, що вивчаються обов'язково набувають спочатку форми мовленнєвого визначення; б) зміст понять постійно поглиблюється і розвивається; в) одиничні поняття підведено під загальніші, а загальні конкретизуються на основі одиничних, при цьому між ними встановлюється взаємозв'язок, у сукупності поняття утворюють як головний складник, систему знань.

4. Методично i науково правильна організації роботи 3 учнями передбачає застосування здобутих географічних знань на практиці у повсякденному житті.

Зауважимо, що процес формування географічної компетенції в учнів основної школи на основі географічних знань має свою специфіку і певні особливості, а саме:

- досить високий рівень абстрактності географічних понять;

- складність міжпонятійних зв'язків, що відображені в цілісній системі законів, категорій і систем у процесі засвоєння географічної інформації; 
- особливо тісний зв'язок теоретичних географічних положень із геополітичним простором, суспільно-економічним і суспільно-політичним життя країни;

- вивчення основ країнознавства в загальноосвітньому закладі передбачає опанування поряд 3 програмним курсом «Географія України» інших курсів природничого циклу, що уможливлює взаємопоєднання і взаємоув'язування здобутих теоретичних знань із подальшим переосмисленням і трансформацією вже сформованих географічних понять.

Висновуємо, що елементами змістового блоку навчальних курсів географії галузі знань «Природничі науки» $\epsilon$ :

1. Поняття - категорії, терміни, поняття, позначення.

Географічне положення - це... (розміщення певного об'єкта, території, країни відносно інших об’єктів, територій, акваторій, країн).

Географічний (територіальний) поділ праці- це... (спеціалізація окремих територій або країн на виробництві певної продукції чи наданні певних послуг).

2. Явища - властивості, явища, факти, спостереження, твердження, опис об'єктів, механізмів тощя (наприклад, розгляд теми «Населення» передбачає вивчення реалізації механізмів і здійснення явищ: природний i механічний рух населення; природний приріст; депопуляція; еміграція/імміграція).

3. Відношення - співвідношення, теореми, закони, концепції, правила, гіпотези, теорії, моделі (аналітичний або графічний опис процесу), залежності (у тому числі аналітичні, графічні та логічні), структури тощзо.

Порівняння показників природного руху населення України і країн Західної Європи.

Побудова секторної та стовпчикової діаграм національного складу населення України.

Аналіз структури зовнішньої торгівлі країни на певному проміжку.

4. Алгоритми - алгоритми діяльності (зокрема алгоритми розв'язування задач (завдань), доведення теорем, рівнянь тощь), послідовності дій, процееури, правила прийняття рішень, поведінки тощчо.

Алгоритм розв’язання проблемних і частково-пошукових завдань географічного спрямування:

Усі гідровузли на ріках побудовані в ХХ $\mathrm{cm}$. Водосховищами зарегульовано 8\% річного і 32\% меженного стоку рік. Яка функиія водосховища важливіша на сучасному етапі розвитку народного господарства задля виробництва електроенергї: як сховища води для зрошення чи водозабезпечення? (Поясніть ие на прикладі Каховського водосховиа).

Чому змінився погляд на використання каналів-не лише для потреб водного транспорту, але $і$ як міжбасейновий перерозподіл води? Чому на території Украйни значно обмежені можливості перекиду вод самотоком? Що є важливішим нині: водосховища задля одержання електроенергї чи електроенергія акумуляційних гідростаниій задля транспортування води? Поясніть ие на прикладі ГЕС Дніпра [4, c. 196-197].

Проілюстровані приклади доводять очевидність того, що рівні сформованості географічних знань співвідносяться із характеристикою діяльності учнів на уроках географії, яка дозволяє об’єктивно визначити ступінь їх сформованості.

Отже, географічна компетенція становить знання учнів про історію, географію, економіку, державний устрій країни, що вивчається. Сформованість географічної культури засвідчує високий рівень географічної культури учнів основної школи, що 
виявляється в географічному баченні світу; географічному мисленні; умінні застосовувати географічні методи і мову (поняття, терміни, карту).

Предметні географічні компетенції- це окремі стосовно ключових i міжпредметних компетенції, що можуть бути конкретно описані і мають формуватися на уроках географії. До предметних географічних компетенцій належать: специфічні для географії знання, вміння й навички та досвід їхнього застосування; досвід творчої діяльності; вміння мислити просторово й комплексно; емоційно-ціннісні установки щодо довкілля та діяльності в ньому (погляди, переконання, ціннісні орієнтації). Системна робота вчителя, спрямована на формування міжпредметних і предметних компетенцій, сприяє всебічному розвитку особистості учня, його вихованню та соціалізації.

\section{Література}

1. Даниленко Л. Експертиза інноваційно-освітніх проектів та технологія іï здійснення / Л. Даниленко. - К. : Директор школи. - 2002. - № 35. - С. 34-38. 2. Зайченко І. В. Педагогіка : [навч. посіб. для студентів вищих пед. навч. закл.] / I. В. Зайченко. - Чернігів, 2003. - 528 с. 3. Подмазин С. И. Теория и практика семестрово-блочно-зачетного режима обучения 12-бального оценивания знаний учащихся : [науч.-метод. пособ.] / С. И. Подмазин. - Запорожье : Просвита, 2000. - 88 с. 4. Топузов О. М. Проблемне навчання географії в школі: теорія і практика : [монографія] / Олег Михайлович Топузов. - К. : Фенікс, 2007. - 304 с.

$$
\text { УДК 378.016:784+174 }
$$

Тетяна Фурдак

\section{ЕМОЦЙНА КУЛЬТУРА ВЧИТЕЛЯ В КОНТЕКСТІ РЕАЛІЗАЦІЇ ВОКАЛЬНО-ХОРОВОЇ УСТАНОВКИ}

Фурдак Т. Д. Емоційна культура вчителя в контексті вокально-хорової установки.

У статті здійснено аналіз психологічної, педагогічної, музикознавчої літератури, запропоновано класифікацію найважливіших типів емоцій, розглянуто важливість розвитку емоційної культури диригента, вчителя музики загальноосвітньої школи у контексті реалізації вокально-хорової установки.

Ключові слова: емоційна культура, хоровий колектив, учитель-диригент, функції емоцій, вокально-хорова установка.

Фурдак Т. Д. Эмоциональная культура учителя в контексте вокально-хоровой установки.

В статье сделан анализ психологической, педагогической, музыковедческой литературы, предложена классификация важнейших типов эмоций, рассмотрена важность развития эмоциональной культуры дирижера, учителя музыки общеобразовательной школы в контексте реализации вокально-хоровой установки.

Ключевые слова: эмоциональная культура, хоровой коллектив, учитель-дирижер, функции эмоций, вокально-хоровая установка.

Furdak T. D. Emotional culture of the teacher in the context of vocal-choral installation.

The article analyzes the psychological, pedagogical, musicological literature, classification of most important types of emotions, discussed the importance of the development of emotional culture of the conductor, music teacher, secondary school, in the context of the implementation of vocal-choral installation.

Key words: emotional culture, choir, teacher, conductor of the function of emotion, vocal-choral setting. 